\title{
PENGEMBANGAN MODEL ANIMASI PEMBELAJARAN PADA PENGOPERASIAN SISTEM PENGENDALIAN ELEKTROMAGNETIK
}

\author{
Lisbeth Siagian ${ }^{1}$ dan Efendi Napitupulu ${ }^{2}$ \\ SMK Negeri 1 Balige ${ }^{l}$ dan Universitas Negeri Medan ${ }^{2}$ \\ lisbethsiagian@gmail.com ${ }^{1}$ dan napitupuluefendi@gmail.com ${ }^{2}$
}

\begin{abstract}
Abstrak: Penelitian ini bertujuan untuk: (1) Mengetahui kualitas model animasi pembelajaran pada mata pelajaran pengoperasian sistem pengendali elektromagnetik yang layak digunakan, mudah dipelajari, (2) Mengetahui keefektifan model pembelajaran animasi pada pengoperasian sistem pengendali elektromagnetik. Jenis penelitian adalah penelitian pengembangan yang menggunakan model pengembangan produk Borg dan Gall. Hasil penelitian menunjukkan bahwa; (1) uji ahli materi pelajaran produktif Teknik Elektro berada pada kualifikasi sangat baik (86,60\%), (2) uji ahli desain pembelajaran berada pada kualifikasi sangat baik (84,70\%), (3) uji ahli rekayasa perangkat lunak berada pada kualifikasi Baik (87,10\%), (4) uji coba perorangan berada pada kualifikasi sangat baik (87,61\%), uji coba kelompok kecil berada pada kualifikasi sangat baik (83,54\%), uji coba lapangan berada pada kualifikasi sangat baik (88,20\%). Hasil pengujian hipotesis membuktikan bahwa terdapat perbedaan yang signifikan antara hasil belajar siswa yang dibelajarkan dengan menggunakan media pembelajaran dengan hasil belajar siswa yang dibelajarkan dengan menggunakan media pembelajaran buku teks. Hal ini ditunjukkan dengan hasil pengolahan data diperoleh $t_{\text {hitung }}=5,547>t_{\text {tabel }}=1,67$ pada taraf signifikansi $\alpha=$ 0,05 dengan dk 61 Disimpulkan bahwa hasil belajar kelompok siswa yang menggunakan media pembelajaran sebesar 75,00\% sedangkan kelompok siswa yang dibelajarkan dengan menggunakan media pembelajaran buku teks sebesar 58,89\%.
\end{abstract}

Kata Kunci: model animasi pembelajaran, pengoperasian sistem pengendalian elektromagnetik

Abstract: This study aims to: (1) Determine the quality of an animated model of learning in the subject of the operation of the electromagnetic control system that is fit for use, easy to learn, (2) Determine the effectiveness of the learning model animation on the operation of the electromagnetic control system. This type of research is the development of research that uses models of product development Borg and Gall. The results showed that; (1) subject matter experts productive test of Electrical Engineering are in excellent qualifications (86.60\%), (2) test the instructional design experts are at a very good qualifying (84.70\%), (3) test software engineering experts are Neither in qualifying (87.10\%), (4) individual testing are at a very good qualifying (87.61\%), small group trial is at a very good qualifying (83.54\%), field trials are in qualifying very good (88.20\%). The test results prove the hypothesis that there are significant differences between student learning outcomes that learned to use the media with student learning outcomes that learned by using learning media textbook. This is indicated by the results of the processing of the data obtained $t=5.547>t$ table $=1.67$ at significance level $\alpha=0.05$ with $61 \mathrm{hp}$ was concluded that the results of the study group of students who use the medium of learning by $75.00 \%$, while the group of students that learned to use instructional media textbook by $58.89 \%$.

Keywords: animated model of learning, the operation of the electromagnetic control system

\section{PENDAHULUAN}

Manfaat aktivitas dalam pembelajaran yang disebabkan oleh kemajuan ilmu dan teknologi adalah agar siswa dapat mencari sendiri dan langsung mengalami proses belajar. Belajar yang dimaksud berupa pembelajaran yang dilaksanakan secara realistik dan kongkrit, sehingga mengembangkan pemahaman dan berpikir kritis serta menghindari terjadinya verbalisme yang terus-menerus. Penyampaian materi ajar yang tidak bervariasi dapat menjadi penyebab tidak tercapainya tujuan pembelajaran yang diinginkan. Dengan 
adanya variasi dalam pembelajaran diharapkan peserta didik dapat berbuat sendiri yang pada akhirnya akan mengembangkan seluruh aspek pribadi.

Peserta didik belajar dan bekerja berdasarkan minat dan kemampuan, sehingga dapat bermanfaat dalam rangka peningkatan potensi individu. Peserta didik dituntut untuk dapat menerapkan semua aspek yang didapat dari proses belajar, sehingga dapat menjadi individu-individu yang kreatif. Suparno seperti dikutip oleh Atmadi dan Setyaningsih (2000: 186) mengemukakan bahwa guru dalam proses belajar mengajar, harus lebih memperhatikan apa yang disukai peserta didik, apa yang tidak disukai peserta didik, yang membantu peserta didik belajar dan yang menghambat peserta didik belajar. Selain itu, strategi yang digunakan juga harus memaksimalkan potensi peserta didik dengan memperhatikan keunikan setiap peserta didik baik gaya belajarnya, kecerdasan dominannya, dan memperhitungkan faktor-faktor lain yang mampu menunjang proses belajar mengajar di kelas.

Berkenaan dengan unsur-unsur yang terdapat dalam pembelajaran guna mendukung proses belajar, maka dibutuhkan suatu alat bantu atau media belajar sebagai sarana pendukung, selain tranformasi belajar secara konvensional atau tatap muka (ceramah) di dalam kelas. Penggunaan alat bantu atau media pembelajaran merupakan bagian yang tidak bisa dipisahkan dan sudah merupakan suatu integrasi terhadap metode belajar yang dipakai. Alat bantu belajar termasuk salah satu unsur dinamis dalam belajar. Kedudukan alat bantu memiliki peranan yang penting karena dapat membantu proses belajar peserta didik. Penggunaan alat bantu, bahan belajar yang abstrak bisa dikongkritkan dan membuat suasana belajar yang tidak menarik menjadi menarik. Banyak alat bantu atau media belajar diciptakan untuk belajar mandiri saat ini, namun untuk mencari suatu pilihan atau solusi alat bantu yang benar-benar baik agar proses belajar menjadi efektif, menarik dan interaktif serta menyenangkan merupakan suatu permasalahan yang perlu dicari solusinya. Alat bantu atau media untuk belajar mandiri pada era kemajuan teknologi sangat dibutuhkan dalam proses pembelajaran. Hal ini dibutuhkan untuk menciptakan kualitas manusia yang tidak hanya bergantung melalui transfer ilmu secara verbal, baik yang dilakukan oleh sekolah maupun perguruan tinggi ataupun lembaga pendidikan nonformal pada saat ini.

Alat bantu atau media pembelajaran dibuat dan dapat digunakan sesuai dengan subyek dan urgensi dari mata pelajaran. Subyek mata pelajaran yang cenderung bersifat hafalan atau teoretis dalam pentransferannya mungkin cukup hanya dengan memakai buku panduan. Lain halnya dengan pembelajaran yang cenderung ke arah aplikatif atau praktek yang membutuhkan informasi tambahan. Dalam pelajaran praktek, dalam memvisualkan suatu bahan ajar terkadang mengalami hambatan yang disebabkan oleh keterbatasan pengajar, peralatan, alat, bahan, biaya dan sebagainya di mana proses penyampaian informasi atau transfer ilmu tidak cukup hanya dengan penyampaian secara verbal (ceramah).

Sistem pengendali elektromagnetik adalah bahasa universal dalam dokumentasi produk engineering, dimana pengendali digunakan sebagai dasar kontrol arus dalam proses menjalankan mesin listrik. Dokumentasi produk engineering meliputi rangkaian pengendali mesin listrik yang memakai media perangkat lunak sesuai dengan perkembangan jaman, akan mendokumentasikan hasil rangkaian-rangkaian pengendali dari suatu proses desain yang nantinya menjadi dasar dalam proses perakitan rangkaian kendali mesin industri dengan sistem kendali elektromagnetik.

Pengembangan media pembelajaran Sistem pengendali elektromagnetik berbantuan komputer, proses pembelajarannya menggunakan media komputer. Menurut Heinich, et.al. (1996:16) pembelajaran yang menggunakan media dapat ditinjau dengan lima perspektif pada teori pembelajaran yaitu behaviorisme, kognitivisme, konstruktrivisme, dan psikologi sosial, serta teori pemrosesan informasi.

Pada teori belajar behavioristik, teori yang banyak berpengaruh dalam perkembangan teknologi pembelajaran seperti yang dikemukakan Heinich, et.al (1996:16) adalah teori kondisioning operan oleh Skinner dengan konsep stimulus respon dan faktor penguatan. Beberapa program yang banyak dipakai dalam teorinya Skinner diantaranya teaching machine dan pembelajaran terprogram yang merupakan cikal bakal pembelajaran berbantuan komputer.

Selain teori pembelajaran behaviorisme sebagai landasan pengembangan media Pengeoperasian Sistem pengendali 
elektromagnetik berbantuan komputer adalah teori belajar kognitif, yang digunakan untuk menyelesaikan problem-problem belajar yang kompleks. Teori belajar kognitif yang sering digunakan adalah Teori Perkembangan Mental Piaget, seperti yang dikemukakan oleh Heinich, et.al. (1996:17), dalam belajar akan ada proses secara tertutup dalam penerimaan materi ke otak sesuai dengan kemampuan peserta didik. Model tutorial dianggap sesuai dengan perkembangan teori kognitif Piaget.

Teori belajar kognitif lainnya adalah Teori Belajar Ausubel (Degeng: 1989). Dalam teori Ausubel ini struktur organisasional yang ada dalam ingatan seseorang dapat diintegrasikan unsur-unsur berpisah ke dalam suatu unit konseptual, yang berarti akan semakna dengan fungsi pengembangan media interaktif berbasis computer pada matapelajaran Pengoperasian Sistem pengendali elektromagnetik itu sendiri. Teori belajar Ausubel merupakan teori belajar konsep sedangkan Sistem pengendali elektromagnetik mempelajari konsep-konsep Sistem pengendali elektromagnetik sehingga ada kesesuaian. Konsep Sistem pengendali elektromagnetik selalu dipelajari dari konsep dasar terlebih dahulu menuju konsep yang lebih sulit.

Teori belajar konstrukrivistik
menjelaskan bahwa dengan dasar konstruktivisme pembelajaran harus dikemas menjadi proses mengkonstruksi bukan menerima pengetahuan. Heinich et.al. (1996:17) mengemukakan bahwa teori belajar konstruktivisme merupakan teori belajar yang menekankan pada pengalaman peserta didik, tidak semata pengetahuan kognitif. Menurut teori konstruktivisme peserta didik membangun sendiri pengetahuannya melalui keterlibatannya secara aktif dalam proses pembelajaran. Selain itu konstruktivisme membantu peserta didik menginternalisasi dan mentransformasi informasi baru pada pembelajaran Sistem pengendali elektromagnetik dengan teori konstruktivisme ini diharapkan akan mampu mengkonstruksi pengetahuan peserta didik dengan berbagai model pembelajaran.

Teori Belajar Psikologi Sosial merupakan gabungan teori belajar behavioristik dan kognitif. Dijelaskan lebih lanjut bahwa teori belajar psikologi sosial menurut teori Vygotsky pengetahuan dan perkembangan kognitif individu berasal dari sumber-sumber sosial di luar dirinya. Ini berarti menekankan peran aktif individu untuk mengkonstruksi pengetahuannya dengan alat-alat yang berfungsi sebagai mediator proses pembelajaran yang didesain secara interaktif. Pemberian umpan balik dengan segera setelah peserta didik menyelesaikan suatu tugas atau kegiatan dimaksudkan untuk merangsang keterlibatan aktif peserta didik tersebut dan merupakan bukti bahwa mereka telah melakukan proses pembelajaran.

Hakikat hasil belajar merupakan tindakan dan perilaku peserta didik yang kompleks. Peserta didik merupakan bagian dari faktor penentu terjadinya proses pembelajaran yang efektif dan efisien. Aktivitas belajar peserta didik merupakan dorongan dari rasa keingintahuan dan merupakan kebutuhan saat itu. Reigeluth (1983:25) secara umum mengkatagorikan indikator keberhasilan peserta didik dalam belajar terdiri dari tiga hal yaitu: (1) efektivitas pembelajaran (effectiveness), yang biasanya diukur dari tingkat keberhasilan peserta didik dalam berbagai hal, (2) efisiensi pembelajaran (efficiency), yang biasanya diukur dari waktu dan pembiayaan, dan (3) daya tarik pembelajaran (appeal), yang selalu diukur dari tendensi peserta didik untuk belajar secara terus menerus. Dengan mengacu pada uraian tersebut dapat disimpulkan bahwa keberhasilan suatu kegiatan pembelajaran dapat dilihat melalui tiga hal, yaitu efektivitas, efisiensi, dan daya tarik.

Belajar merupakan salah satu faktor yang mempengaruhi dan berperan penting dalam pembentukan pribadi dan perilaku individu. Penafsiran kata belajar berbeda-beda oleh banyak pakar pendidikan di Indonesia.

Menurut Slameto (2003:2) menjelaskan bahwa "belajar adalah proses usaha yang dilakukan seseorang untuk memperoleh suatu perubahan tingkah laku yang baru secara keseluruhan sebagai pengalamannya sendiri dalam interaksi dengan lingkungannya".

Menurut Seels dan Richey (1994: 41) pengertian pengembangan adalah proses penerjemahan spesifikasi desain ke dalam bentuk fisiknya. Pengertian tersebut menunjukkan pengembangan merupakan implikasi fungsi teknologi pembelajaran untuk memecahkan masalah belajar dan pembelajaran yang menyangkut segala macam sumber belajar yang berupa pesan orang, bahan, alat, teknik dan lingkungan baik yang digunakan sendirisendiri secara gabungan untuk mempermudah proses pembelajaran.

Menurut Atwi Suparman (2001: 30) pengembangan pembelajaran lebih 
menitikberatkan pada tujuannya yaitu memecahkan masalah belajar, meningkatkan kualitas kegiatan pembelajaran, atau menciptakan situasi kondisi belajar yang memungkinkan peserta didik berinteraksi sehingga terjadi perubahan perilaku melalui suatu proses yang meliputi desain, produksi, dan evaluasi. Prosesnya dimulai dengan mengidentifikasi masalah, mengembangkan strategi dan bahan pembelajaran diakhiri dengan mengevaluasi efektivitas dan efisiensi.

Multimedia dapat sebagai media konstruktivistik yang terdiri dari pembelajaran, peserta didik, proses pembelajaran inilah yang menjadi fokus tidak hanya pengajar atau teknologi yang digunakan. Dalam proses pembelajaran dapat dikatakan teknologi seperti komputer, sebagai alat dalam multimedia dan jaringan web terluas di dunia yang sangat besar pengaruhnya terhadap peserta didik dalam proses pembelajaran. Ciri utama teknologi komputer adalah melibatkan aktivitas interaktif peserta didik dengan berbagai sumber. Pembelajaran dengan berbantuan komputer ini memiliki karakteristik: dapat digunakan secara tidak urut maupun linier sesuai dengan apa yang dikehendaki peserta didik, konsep disajikan secara realistik dalam konteks pengalaman peserta didik, menerapkan prinsip ilmu pengetahuan dan konstruktivitas dan materi disajikan secara interaktif.

Pendekatan ICARE dipelopori Dick dan Carey Model oleh San Diego State University dikembangkan pada Pusat Pengembangan Belajar di Middlesex University menjadi model belajar yang disebut ICARE.

Tabel 1. ICARE Sistem dalam Pembelajaran Interaktive/Model Animasi pembelajaran

Heinich, R., Molenda, M., Russell, J.D., \& Smaldino, S.E. (2002) Instructional Media and Technologies for Learning $-7^{\text {th }}$ ed. Merill Prentice Hall, New Jersey

\begin{tabular}{|l|l|}
\hline Introduction & $\bullet \quad$ This section consists of the introduction to the unit of instruction including: \\
& $-\quad$ Context \\
& - $\quad$ Pbjectives \\
& $-\quad$ Required study time \\
& $-\quad$ Equipment required \\
\hline Connect/Content & Almost all content will reside in this section. \\
\hline Apply & All activities, exercise, thinking questions, etc reside in this section. \\
\hline Reflect & $\begin{array}{l}\text { This section provides time and space for learners to reflect on their acquired } \\
\text { knowledge and articulate their experience. This section may include: } \text { topics for } \\
\text { discussion, a learning journal/log, a self test, an end-of-unit test, etc. }\end{array}$ \\
\hline Extend & $\begin{array}{l}\text { This is an amalgamation of all the previous sections offering materials and } \\
\text { learning opportunities which can be remedial, supplemental, or advanced. }\end{array}$ \\
\hline
\end{tabular}

ICARE system dalam Pengembangan Model Animasi Pembelajaran Pada Pengoperasian Sistem Pengendali Elektromagnetik.

Teknik belajar Aktif telah didokumentasikan pada 490 SM, ketika Socrates menggunakan masalah dan pertanyaan untuk membimbing siswa untuk menganalisis dan berpikir tentang lingkungan mereka (Coltrane, 1993). Teknik-teknik ini telah ditemukan untuk membantu siswa memperoleh pengetahuan, mengembangkan keterampilan berpikir kritis, memecahkan masalah dalam berbagai situasi dan untuk berpikir secara mandiri. Meskipun penelitian lebih lanjut diperlukan untuk mendorong implementasi skala besar, banyak dari strategi individu yang dikembangkan dapat digunakan untuk membantu menyediakan lingkungan belajar yang lebih aktif bagi siswa dalam pelatihan dan pendidikan lingkungan.

Pernyataan di atas menjelaskan bahwa ada dua komunikasi yaitu model psikologi dan mekanik, tetapi bukan untuk memisahkan secara dikotomi. Komunikasi tidak hanya memperlihatkan keseluruhan proses penyampaian pesan (message) dari sumber (source), yaitu dosen kepada penerima pesan (receiver), yaitu peserta didik. Efek pesan harus dapat mencapai tujuan komunikasi, yaitu memperoleh respon atau umpan balik yang ditunjukkan dengan perubahan perilaku sebagai hasil belajar. 
Model Komunikasi yang paling sederhana dikemukakan oleh Schram (Heinich et.al, 1995: 13) yang mengidentifikasi dan menganalisa langkah-langkah terjadinya komunikasi. Model Komunikasi digambarkan oleh Schram (Heinich et.al) sebagaimana terdapat pada Gambar 1.

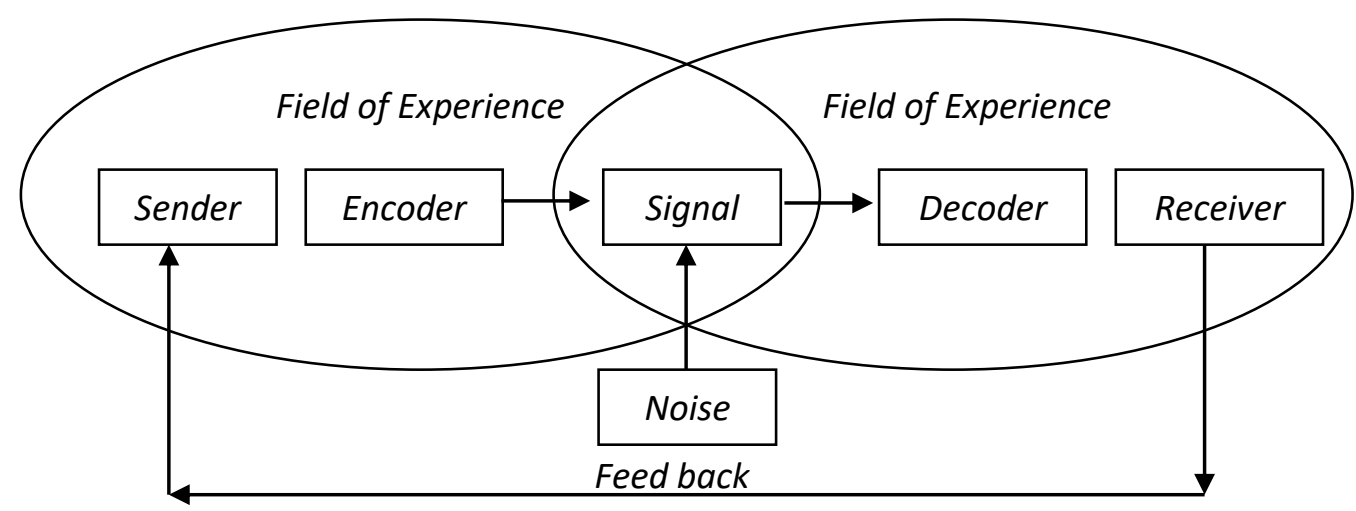

Gambar 1. Skema Model Komunikasi

Gambar skema tersebut dapat disimpulkan bahwa materi akan disampaikan pada peserta didik, sehingga mereka dapat menguasainya sebagai pesan. Instruktor/guru sebagai sumber pesan (sender) menuangkan pesan ke dalam simbol tertentu (enconding) dan peserta didik sebagai penerima pesan (receiver) menafsirkan simbol sehingga dipahami sebagai pesan (decoding), meskipun ada gangguan (noise) dalam berkomunikasi, misalkan yang terjadi di kelas yaitu: suara kurang jelas, tulisan yang kurang jelas atau cahaya yang kurang jelas.

Menurut Russel (1974: 1) Individualized intruction is meant who whatever arragment make it possible for each student to be engaged at all times in learning those things that are of most value himself, as an individual", sedangkan Kemp (1994: 147) mengemukakan bahwa metode belajar sesuai dengan kecepatan sendiri disebut belajar mandiri, pengajaran sendiri, atau belajar dengan mengarahkan sendiri.

Salah satu sistem pembelajaran yang sesuai dengan pembelajaran individual adalah pembelajaran dengan modul seperti yang dikemukakan oleh Kemp (1994: 147). Istilah modul pada awalnya merupakan istilah dalam bidang teknik yang diambil oleh dunia pendidikan untuk menunjukkan suatu konsep baru tentang unit program pembelajaran. Menurut Russel (1973: 13), sumber belajar yang berupa pembelajaran mandiri mempunyai ciri-ciri umum, yaitu: (1) Self- contained, self instroduction packase, (2) Concern for individual differencesof knowledge, (3) Statement of objectives, (3) Assosiation, structure and sequnce of knowledge, (4) Utilization of varieties of media, (5) Active partisipation by the leaner, (6) Immediate reinforcement of responses, (7) Mastery evaluation stategy.

Lukmanul Hakim (2004: 2) menyebutkan bahwa Flash MX 2004 merupakan alat yang sangat bagus untuk desainer web, praktisi media interaktif, atau praktisi multimedia. Penekanan Flash untuk pembuatan (kreasi) animasi, serta mengimpor dan memanipulasi berbagai tipe media (audio, video, bipmap, vektor, teks, grafik, dan data). Di dalam bukunya yang lain Lukmanul Hakim \& Mutmainah (2003), menyebutkan bahwa Macromedia Flash MX adalah (1) program grafis animasi standar professional, (2) berbasis vektor, dengan movie flashnya (yang terdiri dari grafik, teks, animasi), (3) mampu untuk menghasilkan halaman web yang menarik, (4) bisa diakses lebih cepat dan terlihat halus pada skala resolusi layar berapapun, (5) karena adanya Actionscript (suatu bahasa pemrograman berorientasi objek) maka bisa memasukkan unsur interaktif dalam movienya, (6) bagi para desainer, Flash menyediakan kemampuan yang lebih tinggi dan mempermudah dengan tool desain yang banyak, sehingga dapat membantu 
mereka agar lebih cepat dalam menciptakan suatu kreasi karya yang bagus dan berbobot, (7) bagi para pengembang, Flash menyediakan script yang lebih komplek dan canggih, referensi kode yang lebih banyak, tool debug yang dapat memeriksa kesalahan, dan pendefinisian komponen untuk, aplikasi web, sehingga dapat digunakan untuk membangun aplikasi web yarg lebih menarik dan dapat diandalkan.

Fasilitas-fasilitas baru di dalam Flash MX 2004 semakin memperkaya kemampuan, kreativitas, dan kekuatan Flash. Fitur-fitur terbaru yang ditambahkan pada Flash MX 2004 cukup banyak. Lukmanul Hakim (2004: 5) membaginya menjadi 4 kategori yaitu: (1) kategori produktivitas meliputi: efek-efek timeline, behaviors, dukungan accessibility yang lebih baik, tambahan template baru, halaman pembuka, sistem help yang terintegrasi, tab dokumen, spell checker (Memeriksa Ejaan), find and replace, (2) dukungan media yang lebih banyak, meliputi: wizard untuk mengimpor video, mengimpor dengan kualitas tinggi (High-Fidelity), mampu me-render font yang ukurannya kecil, (3) kategori publikasi, meliputi: mendeteksi Flash Player, profil Publikasi, mendukung Unicode, String Panel, keamanan. (4) Fitur-fitur terbaru lainnya, meliputi: mendukung CSS (Cascading Style Sheet), History Panel, Polystar Tool, Free Transform Tool, tambahan komponen (Components) baru, terintegrasi dengan Flash Remoting, Extensions bagi Developer ThirdParty, peningkatan pada Timeline, ActionScript versi 2. Pada Action Script ini telah ditambahkan fungsi-fungsi yang sangat kompleks dan berdayaguna, dukungan penuh terhadap OPP (Object Oriented Programming) atau pemrograman berorientasi objek dan pemrograman standar ECMA (European Computer Manufacturers Association). Action Script 2.0 ini akan tampak sangat familiar bagi programmer lava, dan Flash Player 7.

Alasan utama mengapa Flash dipilih sebagai authoring tool pada penelitian ini adalah dibanding tool-tool yang lain, animasi Flash ini berbasis vektor. Ini menguntungkan karena objek vektor dapat diperbesar dan tetap cantik sempurna tidak pecah, juga cepat downloadnya. Animasi Flash mempunyai ukuran file yang jauh lebih kecil dan bersifat streaming. Artinya, begitu sekian byte data awal file telah didownload, animasi dapat langsung dijalankan. Karena ukuran file (.swf)nya yang kecil maka ini akan menguntungkan apabila produk penelitian ini ke depan akan di up-load atau ditaruh di dalam web site sekolah sebagai e-learning. Kemampuan streaming inilah merupakan salah satu alasan mengapa Flash lebih disukai ketimbang/daripada yang lain. Mengutip dari majalah Master Web bahwa sebetulnya flash bukan satu-satunya teknologi animasi web yang ada. Macromedia Flash sendiri bukan satusatunya authoring tool yang dipakai orang. Selain Applet Java, dikenal juga Microsoft Liquid Motion, Adobe Live Motion, dan Corel Rave. Namun nampaknya belum ada yang berhasil meruntuhkan kejayaan Macromedia Flash.

Pembelajaran konvensional sampai saat ini masih banyak digunakan oleh guru dalam kegiatan belajar mengajar di kelas. Konvensional merupakan pembelajaran yang berpusat pada guru, sehingga dalam kegiatan belajar mengajar gurulah yang berperan aktif.

Lebih lanjut Muslich (2008:40) mengatakan bahwa pembelajaran konvensional hanya menekankan pada tingkat hafalan dari sekian banyak topik atau bahasan, tetapi tidak diikuti dengan pemahaman atau pengertian yang mendalam, konsep akademik yang diperoleh peserta didik hanyalah merupakan sesuatu yang abstrak, belum menyentuh kebutuhan praktis kehidupan mereka, yang bisa diterapkan ketika peserta didik berhadapan dengan situasi baru dalam kehidupannya.

Berdasarkan pendapat di atas, maka dapat disimpulkan bahwa penerapan pembelajaran konvensional di dalam kelas, pengajar lebih mudah untuk mempersiapkan dan melaksanakan karena pengajar dapat menguasai kelas dengan baik, akan tetapi siswa akan menjadi pasif dan kurang mengerti tentang apa yang disampaikan pengajar. Pembelajaran konvensional guru memegang otoritas pembelajaran tanpa memberikan kesempatan siswa untuk berinteraksi dan bersosialisasi. Jadi, pembelajaran konvensional cenderung berasumsi bahwa siswa memiliki tingkat kemampuan yang sama, kebutuhan yang sama, belajar dengan perlakuan yang sama, pada waktu yang sama dengan materi pelajaran yang berstruktur dan di dominan oleh guru sehingga siswa berperan sebagai pengikut dan penerima pasif dari kegiatan pembelajaran yang dilaksanakan. pembelajaran konvensional ini sering diidentikkan dengan metode ceramah, tanya jawab dan pemberian tugas.

Masalah yang akan diteliti dalam penelitian ini dapat dirumuskan sebagai 
berikut: (1) Bagaimana tanggapan siswa terhadap kualitas model animasi pembelajaran pada mata pelajaran pengoperasian sistem pengendali elektromagnetik?; dan Bagaimana keefektifan model pembelajaran animasi pada pengoperasian sistem pengendali elektromagnetik?

\section{METODE}

Penelitian ini dilaksanakan di SMK Negeri 1 Balige semester III Jurusan Teknik Instalasi Tenaga Listrik. Metode penelitian yang digunakan adalah research and development, karena penelitian ini termasuk penelitian pengembangan pendidikan yang dimaksudkan untuk menghasilkan produk pembelajaran yang layak dimanfaatkan dan sesuai kebutuhan. Borg dan Gall (1983) memberikan batasan tentang penelitian pengembangan sebagai usaha untuk mengembangkan dan memvalidasi produkproduk yang digunakan dalam pendidikan.

Dari berbagai pendapat tersebut dapat ditarik kesimpulan bahwa metode yang digunakan dalam penelitian merupakan suatu jenis penelitian untuk menghasilkan produkproduk untuk kepentingan pendidikan atau pembelajaran melalui pengembangan, dan validasi produk-produknya diakhiri dengan evaluasi.

Model pengembangan merupakan serangkaian prosedur dalam rangka menghasilkan media pembelajaran mata pelajaran pengoperesian sistem pengendali elektromagnetik untuk peserta didik SMK Negeri 1 Balige semester III. Model pengembangan yang dipakai merupakan adaptasi dari model pengembangan multimedia Luther (Hadi., 2003: 32).

Adapun langkah-langkah dari tahapan pengembangannya adalah sebagai berikut :

1. Melakukan penelitian pendahuluan, yang meliputi:

a. Identifikasi kebutuhan pembelajaran dan menentukan standar kompetensi mata pelajaran.

b. Melakukan analisis pembelajaran.

c. Mengidentifikasi karakteritik dan perilaku awal siswa.

d. Menulis kompetensi dasar dan indikatornya.

e. Menulis tes acuan patokan. f. Menyusun strategi pembelajaran yang diwujudkan dalam bentuk silabus dan satuan pembelajaran.

g. Mengembangkan materi pembelajaran.

2. Pembuatan desain software, yang meliputi:

a. Pembuatan naskah

b. Pembuatan storyboard

c. Pembuatan flowchart view

3. Pengumpulan bahan, yang meliputi:

a. Pembuatan dan pengumpulan gambar (image) dan animasi.

4. Mengembangkan dan membuat Media Pembelajaran Interaktif Berbasis Komputer Pada matapelajaran Pengoperasian Sistem Pengendali Elektromagnetik .

5. Review dan uji coba produk.

Prosedur pengembangan yang ditempuh untuk menghasilkan produk pembelajaran berbantuan komputer dibagi menjadi 5 tahap, yaitu : (1) tahap pertama melakukan penelitian pendahuluan, tahap ini diawali dengan Identifikasi Kebutuhan Pembelajaran dan Menentukan Standar Kompetensi mata pelajaran, Melakukan Analisis Pembelajaran, Mengidentifikasi Karakteristik dan Perilaku Awal peserta didk, Menentukan Kompetensi Dasar serta Indikator, Menulis Tes Acuan Patokan, Mengembangkan Materi Pembelajaran, (2) tahap kedua pembuatan desain media, Pada tahap ke dua ini diawali dengan pembuatan desain software, Pembuatan Naskah, Pembuatan Storyboard, Pembuatan Flowchart view (3) tahap ketiga pengumpulan bahan, diawali dengan pengumpulan bahan pembuatan dan pengumpulan gambar animasi, perekaman dan pengumpulan audisi (4) tahap keempat membuat dan memproduksi Media Pembelajaran Interaktif Berbasis Komputer, yang dilengkapi dengan petunjuk-petunjuk media seperti: petunjuk belajar, deskripsi singkat, kompetensi dasar, uraian materi, soalsoal latihan dan balikan, yang terakhir sebagai penutup adalah rangkuman dan (5) tahap kelima yaitu review atau uji lapangan dalam rangka evaluasi formatif dan revisi produk. Evaluasi formatif terus berlangsung selama proses pengembangan mulai dari tahap analisis, desain, produksi maupun implementasi sampai diperoleh hasil yang sesuai dengan tujuan yang telah ditetapkan.

Model Rancangan Eksperimen

Table 2. Desain Penelitian 


\begin{tabular}{|c|c|}
\hline \multicolumn{2}{|c|}{ Media Pembelajaran Interaktif Berbasis Komputer } \\
Pada Matapelajaran Mengoperasikan Sistem Pengendali Elektromagnetik \\
\hline Mengunakan Media & Menggunakan \\
Pembelajaran Interaktif (Animasi) & Cara Konvensional \\
(A1) & $(\mathrm{A} 2)$ \\
\hline$\mu \mathrm{A} 1$ & $\mu \mathrm{A} 2$ \\
\hline
\end{tabular}

Keterangan:

$\mu$ A1 : Hasil belajar Mengoperasikan Sistem

Pengendali Elektromagnetik menggunakan Model Animasi Pembelajaran

$\mu \mathrm{A} 2 \quad$ : Hasil belajar Mengoperasikan Sistem Pengendali Elektromagnetik menggunakan cara konvensional

\section{HASIL DAN PEMBAHASAN Hasil}

Rangkuman persentase rata - rata hasil penilaian terhadap media pembelajaran mata pelajaran produktif Teknik Elektro oleh ahli materi, ahli desain pembelajaran, ahli rekayasa perangkat lunak, uji coba perorangan, ujicoba kelompok kecil dan uji coba lapangan dapat dilihat pada Table 3 berikut

Tabel 3. Rangkuman Persentase Rata-Rata Hasil Penilaian Terhadap Media Pembelajaran Mata Pelajaran Produktif Teknik Elektro

\begin{tabular}{|l|l|c|c|}
\hline No & Responden & Rata-Rata & Kriteria \\
\hline 1 & Ahli materi & $86,60 \%$ & Sangat Baik \\
\hline 2 & Ahli desain pembelajaran & $84,70 \%$ & Sangat Baik \\
\hline 3 & Ahli rekayasa perangkat lunak & $87,10 \%$ & Sangat Baik \\
\hline 4 & Siswa pada uji coba perorangan & $87,61 \%$ & Sangat Baik \\
\hline 5 & Siswa pada uji coba kelompok kecil & $83,54 \%$ & Sangat Baik \\
\hline 6 & Siswa pada uji coba lapangan & $88,20 \%$ & Sangat Baik \\
\hline \multicolumn{2}{|c|}{ Rata-Rata } & $86,29 \%$ & Sangat Baik \\
\hline
\end{tabular}

\section{Efektifitas Media Pembelajaran}

Untuk melihat efektifitas media pembelajaran diperlukan pembanding pembelajaran yang lain dalam hal ini menggunakan menggunakan buku teks. Uji-t dipergunakan untuk mengetahui perbedaan hasil belajar. Berdasarkan hasil perhitungan yang diperoleh $t_{\text {hitung }}$ sebesar 5,475 dan $t_{\text {tabel }}$ 1,67 pada taraf kepercayaan $95 \%$. Perhitungan selengkapnya terdapat pada lampiran 14. Dengan demikian dapat disimpulkan bahwa terdapat perbedaan yang signifikan antara hasil belajar siswa dengan media pembelajaran dengan siswa yang diajar dengan buku tekspada $\alpha=5 \%$

Keefektifan media pembelajaran diperoleh dengan cara sebagai berikut:

$$
\begin{aligned}
& \mathrm{X} \\
& =\frac{\text { Jumlah skor yang diperoleh }}{\text { Jumlah skor ideal seluruh item }} \times 100 \% \\
& \qquad \mathrm{X}=\frac{840}{1120} \times 100 \%=75,00 \%
\end{aligned}
$$

Sedangkan keefektifan pembelajaran dengan buku teks diperoleh

$$
=\frac{\text { Jumlah skor yang diperoleh }}{\text { Jumlah skor ideal seluruh item }} \times 100 \%
$$

$$
\mathrm{X}=\frac{639}{1085} \times 100 \%=58,89 \%
$$

Dari hasil perhitungan diketahui keefektifan media pembelajaran lebih tinggi dari pembelajaran menggunakan buku teks .

\section{Pembahasan}

Produk pengembangan media pembelajaran pada mata pelajaran produtif Teknik Elektro merupakan materi pembelajaran produktif Teknik Elektro yang dikembangkan dengan memperhatikan aspek pembelajaran dan media sebagai prinsip desain pesan pembelajaran. Penelitian pengembangan produk yang dilakukan ini diarahkan untuk menghasilkan suatu produk berupa media pembelajaran mata pelajaran produktif Teknik Elektro untuk peserta didik SMK program Teknik Elektro kelas XI semester ganjil yang digunakan untuk meningkatkan proses pembelajaran maupun kompetensi peserta didik. Karena itu dalam prosesnya penelitian ini dilakukan dengan diawali studi pendahuluan, kemudian mendesain media pembelajaran, melakukan validasi produk, melakukan revisi produk, dan penyempurnaan berdasarkan analisis data validasi ahli materi, ahli desain 
pembelajaran dan ahli rekayasa perangkat lunak yang dilanjutkan dengan uji coba perorangan, uji coba kelompok kecil dan uji coba lapangan sehingga dihasilkan media pembelajaran yang layak digunakan sesuai dengan karakteristik mata pelajaran produktif Teknik Elektro dan peserta didik sebagai pengguna.

Aspek yang direvisi dan disempurnakan berdasarkan analisis data dan uji coba serta masukkan dari ahli materi, ahli desain, ahli rekayasa perangkat lunak dan peserta didik selaku pengguna media pembelajaranini, bertujuan untuk menggali beberapa aspek yang lazim dalam proses pengembangan suatu produk. Variabel- variabel media pembelajaran memiliki nilai rata - rata sangat baik.Adapun variabel media pembelajaran yang dinilai meliputi kelayakan isi,

Manfaat yang diperoleh dari penggunaan media pembelajaran adalah konsep yang disajikan mudah dipelajari, dipahami, dan sistematis. Media pembelajaran memberikan kesempatan pada peserta didik untuk belajar sesuai dengan kecepatan masing-masing, belajar lebih cepat dan tidak menimbulkan kebosanan karena dilengkapi dengan gambargambar,selain itu media pembelajaran yang digunakan dapat interaktif terhadap peserta didik sehingga hal ini akan menyenangkan dalam pembelajarannya karena peserta didik dapat mengoreksi hasil jawaban soal yang dikerjakan benar atau salah. Adanya pengulangan yang dilakukan saat jawaban salah menjadikan peserta didik lebih memahami materi.Media pembelajaran ini juga dapat digunakan sebagai alternatif media pembelajaran secara klasikal maupun individual.

Dari hasil pengolahan data penelitian yang dilakukan, terdapat perbedaan hasil belajar produktif Teknik Elektro antara peserta didik yang dibelajarkan dengan menggunakan media pembelajaran dengan peserta didik yang dibelajarkan dengan media buku teks, yaitu nilai rata - rata hasil belajar produktif Teknik Elektro yang dibelajarkan dengan media pembelajaran lebih tinggi dibandingkan dengan nilai rata-rata hasil belajar peserta didik yang dibelajarkan dengan menggunakan media buku teks. Hal dapat dilihat dari nilai rata-rata hasil belajarproduktif Teknik Elektro peserta didik yang dibelajarkan dengan menggunakan media pembelajaran yaitu sebesar 26,25 (75\%). Sedangkan nilai rata-rata hasil belajar produktif
Teknik Elektro peserta didik yang dibelajarkan dengan menggunakan media buku teks yaitu sebesar20,61 (58,89\%). Dari data ini membuktikan bahwa penggunaan media pembelajaran lebih baik dalam meningkatkan pengetahuan peserta didik dalam pembelajaran produktif Teknik Elektro dari pada penggunaan media buku teks.

Penggunaan media pembelajaran dalam pembelajaran produktif Teknik Elektro memungkinkan peserta didik untuk berinteraksi langsung dan melakukan kontrol langsung pada sumber informasi, sehingga peserta didik dapat mengendalikan dan memperoleh apa yang menjadi kebutuhannya. Peserta didik juga dapat mengerjakan soal-soal latihan yang telah dilengkapi dengan balikan dan pembahasan sehingga peserta didik dapat mengetahui kesalahan yang telah dilakukan dalam mengerjakan soal latihan tersebut.Media pembelajaran juga dilengkapi dengan rangkuman yang dapat membantu peserta didik memperoleh ringkasan materi pelajaran yang dipaparkan.

Pembelajaran dengan media pembelajaran juga memungkinkan guru bebas melakukan interaksi dengan siswa sehingga pembelajaran tersebut lebih berinteraksi yang membuat pembelajaran lebih terfokus pada informasi yang sedang dipelajari. Tentunya ini berbeda dengan pembelajaran menggunakan media buku teks, peserta didik tidak berinteraksi langsung pada sumber informasi dan pembelajaran lebih banyak didominasi oleh guru yang menyajikan informasi secara linier atau satu arah, keadaan ini terjadi karena pada media pembelajaran buku teks peserta didik mendapatkan sumber informasi setelah mendengar penjelasan dari guru dan materimateri yang ada pada buku teks tanpa bisa memperoleh balikan dari soal-soal latihan yang dikerjakan. Pembelajaran dengan menggunakan media pembelajaran buku teks menempatkan guru menggunakan kontrol pembelajaran dengan aktif, sementara peserta didik relative pasif menerima dan mengikuti apa yang disampaikan guru. Guru menyampaikan materi secara terstruktur dengan harapan materi pelajaran yang disampaikan dapat dikuasai dengan baik dengan terfokus kepada kemampuan akademik.

Walaupun dalam penelitian diperoleh data bahwa hasil belajar produktif Teknik Elektro peserta didik lebih tinggi jika dibelajarkan dengan menggunakan media 
pembelajaran dari pada hasil belajar produktif Teknik Elektro peserta didik yang dibelajarkan dengan menggunakan media buku teks, akan tetapi dalam pelaksanaannya media pembelajaran dan media buku teks telah mampu meningkatkan pemahaman dan hasil belajar produktif Teknik Elektro peserta didik.

\section{PENUTUP}

\section{Simpulan}

Berdasarkan rumusan, tujuan, hasil dan pembahasan penelitian pengembangan media pembelajaran yang dikemukakan sebelumnya, maka dapat disimpulkan sebagai berikut:

1) Setelah melewati beberapa tahapan mulai dari validasi oleh ahli materi, validasi oleh ahli desain pembelajaran, dan validasi oleh ahli rekayasa perangkat lunak, lalu uji coba perorangan, uji coba kelompok kecil, sampai dengan uji lapangan kepada peserta didik, produk media pembelajaran untuk mata pelajaran produktif Teknik Elektro memiliki hasil sudah layak menjadi produk akhir yang dapat disebarluaskan dan diimplementasikan kepada para pengguna. Hal ini diperjelas dengan perolehan terhadap penilaian yang rata-rata hampir semua tahapan, dimulai pada validasi ahli materi total nilai rata-rata keseluruhan adalah $82,93 \%$ dalam tabel skala lima, nilai tersebut dalam kategori sangat baik, pada validasi ahli desain pembelajaran total nilai rata-rata keseluruhan adalah $85,07 \%$ dalam tabel skala lima, nilai tersebut termasuk kategori sangat baik. Sedangkan validasi untuk ahli rekayasa perangkat lunak total nilai rata-rata keseluruhan adalah $82,84 \%$ dalam tabel skala lima, nilai tersebut termasuk kategori sangat baik, sedangkan pada uji coba kelompok perorangan total nilai rata-rata keseluruhan adalah $87,61 \%$ dalam tabel skala lima, nilai tersebut termasuk kategori sangat baik, pada uji coba kelompok kecil total nilai rata-rata keseluruhan adalah $83,54 \%$ dalam tabel skala lima, nilai tersebut termasuk kategori sangat baik, dan pada uji coba lapangan total nilai rata-rata keseluruhan adalah $88,16 \%$ dalam tabel skala lima, nilai tersebut termasuk kategori sangat baik,

2) Untuk melihat efektifitas produk, dilakukan analisis terhadap hasil belajar peserta didik. Berdasarkan analisis dari 32 peserta didik uji coba kelompok besar hasil penggunaan media pembelajaran produktif Teknik
Elektro pada tes hasil belajar peserta didik menunjukkan bahwa hasil belajar peserta didik yang dibelajarkan dengan menggunakan media pembelajaran produktif Teknik Elektro nilai rata-rata $=26,25$ lebih tinggi dari tes hasil belajar peserta didik yang dibelajarkan dengan menggunakan media pembelajaran buku teks, yaitu dengan nilai rata-rata $=20,61$. Dengan demikian dapat disimpulkan bahwa hasil belajar peserta didik yang dibelajarkan dengan menggunakan media pembelajaran produktif Teknik Elektro lebih efektif dari pada dengan hasil belajar peserta didik yang dibelajarkan dengan media pembelajaran buku teks, diketahui juga data hasil media pembelajaran produktif Teknik Elektro memiliki keefektifan sebesar 75\% lebih tinggi dari keefektifan media pembelajaran menggunakan media buku teks sebesar $58,89 \%$

\section{Saran}

Berdasarkan hasil yang telah diuraikan pada simpulan serta implikasi hasil penelitian, berikut ini diajukan beberapa saran yaitu:

1. Selama ini proses pembelajaran masih menggunakan media cetak, maka disarankan agar dapat menambahkan media pemebelajaran ini sebagai salah satu media pembelajaran yang digunakan untuk proses pembelajaran, sehingga kegiatan pembelajaran lebih bervariasi, menarik dan tidak membosankan .

2. Media pembelajaran produktif Teknik Elektro memerlukan adanya fasilitas yang memadai untuk menggunakannya, sehingga para peserta didik dapat melakukan kegiatan belajar bersama maupun mandiri yang mana akan lebih efisien dalam menggunakan waktu belajar dan memiliki waktu yang cukup panjang untuk memahami materinya serta dapat mengulang kembali materi yang belum dapat dipahami.

3. Kepada Guru agar kiranya memberi motivasi kepada peserta didik untuk dapat belajar dengan menggunakan media pembelajaran, karena peserta didik akan mendapatkan informasi yang mereka inginkan sesuai kemampuan masing-masing melalui media pembelajaran ini dan peserta didik juga tidak tergantung terhadap kehadiran guru dalam upaya meningkatkan hasil belajarnya. 
DAFTAR PUSTAKA

Atmadi, A dan Y. Setyaningsih. 2000. Tansformasi Pendidikan Memasuki Millenium Ketiga. Yogyakarta: Kanisius

AECT. (1977). Definisi teknologi pendidikan (satuan tugas definisi \& terminologi AECT). Jakarta. Rajawali.

Arikunto, Suharsimi. (2006). Prosedur Penelitian Suatu Pendekatan Praktik. Jakarta : Rineka Cipta.

Budiningsih, Asri . (2003). Desain pesan pembelajaran. Yogyakarta : Fakultas Ilmu Pendidikan Universitas Negeri Yogyakarta.

(2003). Belajar dan pembelajaran. Yogyakarta : Fakultas Ilmu Pendidikan Universitas Negeri Yogyakarta.

Borg, W. \&V Gall, M.D. (1983). Educational research. An introduction ( $4^{\text {nd }}$ ed). New York \& London: Longman.

Dick, W. dan Cary, L. (2005). The systematic design of instruction. United States of America: Scott Foresman and Company.

Djamarah dan Zein. 2006. Strategi Belajar Mengajar. Jakarta: Rineka Cipta.

Gagne, Robert M and Briggs, Leslie J. (1979). Principles of Instructional Design $\left(2^{\text {nd }}\right.$ $E d$.$) . New York: Holt, Rinehart and$ Winston.

Hacbart, Steven. (1996). The educational technology hand book. New Jersey. Educational Technology Publications, Inc.

Heinich, Robert, et. Al. (1996) Instructional media and technologies for learning $\left(5^{\text {th }}\right.$ ed). New Jersey : A Simon \& Schuster Company Engelewood Cliffs.

Himpunan Peraturan Perundang-undangan. (2005). Standar nasional pendidikan (SNP). Bandung: Fokusmedia.

Hornby. A.S. 1985. Oxford Advanced Learner's Dictionary of Current English, Oxford USA: Oxford University Pres.

Hakim, Lukmanul. (2003). Teknik jitu menguasai macromedia flash MX 2004. Jakarta: Elex Media Komputindo.

(2004). Cara ampuh menguasai macromedia flash MX 2004. Jakarta: Elex Media Komputindo.

IKAPI DKI dan BSNP. (2006). Sosialisasi teknis standar mutu isi dan grafika dalam penilaian buku teks pelajaran 2006.

IKAPI DKI Jakarta dan BSNP. (2006). Makalah sosialisasi teknis standar mutu isi dan grafika dalam penilaian buku teks pelajaran 2006. Jakarta: BSNP.

Kemp. (1994). Design effective instruction. New York: Macmillan College Publishing Company.

Kumpulan Abstrak Seminar Nasional Kimia XVII .(2005). Pembelajaran kimia berbasis kompetensi. Yogyakarta: Jurusan Kimia. FMIPA Universitas Gadjah Mada.

Lambert, (1992). Why interactive multimedia based computer aided learning (IMMCAL). Diambil tanggal 5 Januari 2006, dari http://www.ascilite.org.au/asetarchives/c onfs/iims/1992/lambert-t.html

Mukminan. (2004). Desain pembelajaran. Yogyakarta: Program Pascasarjana Universitas Negeri Yogyakarta.

Mansur, Muslich. 2008. KTSP. Pembelajaran Berbasis Kompetensi dan Kontekstual. Jakarta : Bumi Aksara.

Nolker,. Helmut and Schoenfeldt, Eberhard. 1988. berufsbildung: Unterricht, Curriculum, Platung ( Pendidikan Kejuruan: Pengajaran, Kurikulum, Perencanaan). Penerjemah: Agus Setiadi. Jakarta: P.T. Gramedia.

Porter Boby et all, (2001). Quantum teaching. Jakarta : Kaifa

Romiszowski. (1988). The selection and use of instructional media. United States: Nichols Publishing.

Russel, JD. (1974). Modular instruction. Amerika: Burgess Publishing Company.

Sagala, Syaiful. 2005. Konsep dan Makna Pembelajaran. Bandung: Alfabeta.

Santoso, Singgih. 2008. Buku Latihan SPSS Statistik Parametrik 16 . Jakarta: Elex Media Komputindo.

Sleeman, Philip. J. (1979). Instructional media and technology. New York: Long man Inc.

Jakarta : Pustekkom Dikbud.

Suparman M, Atwi. (2001). Desain instruksional. Pusat antar Universitas untuk Peningkatan dan Pengembangan Aktivitas Instruksional. Jakarta: Direktorat Jenderal Pendidkan Tinggi, Departemen Pendidikan Tinggi. (2001).

Sudjana, Nana. 2004. Penilaian Hasil Proses Belajar Mengajar. Bandung : Rosdakarya.

Sudjana. 2002. Metoda Statistika. Bandung: Tarsito. 
Sudjana. 2005. Media Pengajaran. Bandung : Sinar Baru Algensindo

Sugiyono. 2003. Metode Penelitian Administrasi. Bandung : CV. Alfabeta.

(2010). Metode Penelitian Kuantitatif, Kualitatif dan $R \& D$. Bandung: Alfabeta.

Sukardjo. (2000). Kecenderungan baru (trend) teknologi pembelajaran kimia. Makalah disajikan pada Seminar Regional di Jurdik Kimia UNY. . (2003). Evaluasi pembelajaran. Diktat Mata Kuliah Evaluasi
Pembelajaran . Tidak diterbitkan PPs . UNY.

Waldopo. (2002). Penelitian dan pengembangan, pendekatan dalam mengembangkan produk-produk di bidang pendidikan pembelajaran. Jurnal Teknodik. Desember 2002. Jakarta: Pustekkom.

Heinich, R., Molenda, M., Russell, J.D., \& Smaldino, S.E. (2002) Instructional Media and Technologies for Learning $7^{\text {th }}$ ed. Merill Prentice Hall, New Jersey 